Pleno De Jure, Vol. 4, No. 5, Desember 2015

\title{
PENGARUH KEBIJAKAN PUBLIK TERHADAP KUALITAS PELAYANAN, PENGUATAN KELEMBAGAAN DAN KINERJA ORGANISASI PEMERINTAHAN
}

\author{
H. Rusdin Nawi \\ Universitas Satria Makassar
}

Abstract

The low of government performance in Indonesia occured because the institution which not support in actualization it, to rise of service perception which less quality. This caused the public policy by government not to formulation, implemented and evaluated with good, which affected toward the quality of service, public policy toward institution and public policy toward performance.

The research aims to know and analysis the affected of public policy toward service quality and performance, public policy toward the strength of institution and performance, the service quality and the strength of institution toward performance.

The method of analysis with quantitative and observation survey approach with sample used Slovin formulation. Data analysis with SEM from computer aims AMOS 18.

The result of research to found that the public policy have negative and significant toward service quality and performance, the public policy have positive and significant toward the institution have positive and significant toward performance.

The research implication that the public policy reguired to formulation with good suitable with implementation which to be process in appointment of achieve the result of work which can to evaluation in implementation of service quality, institution and achieve of performance. Keywords: Public policy, service, insitution and performance

Abstrak
Rendahnya kinerja organisasi pemerintah di Indonesia terjadi karena kelembagaan yang mendukung lemah dalam aktualisasinya,
menimbulkan persepsi pelayanan yang kurang berkualitas. Ini terjadi dikarenakan kebijakan publik yang diterapkan oleh instansi pemerintah tidak terformulasikan, terimplementasikan dan terevaluasikan dengan baik, yang berpengaruh terhadap kualitas pelayanan, kebijakan publik terhadap kelembagaan dan kebijakan publik terhadap kinerja organisasi.

Tujuan penelitian untuk mengetahui dan menganalisis pengaruh kebijakan publik terhadap kualitas pelayanan dan kinerja organisasi, pengaruh kebijakan publik terhadap penguatan kelembagaan dan kinerja organisasi, pengaruh kualitas pelayanan dan penguatan kelembagaan terhadap kinerja organisasi.

Metode penelitian menggunakan jenis penelitian kuantitatif dengan pendekatan survei observasi dengan menentukan sampel dilakukan dengan menggunakan rumus Slovin. Analisis data yang digunakan yaitu SEM (Structure Equation Models) dengan bantuan program komputer AMOS 18.

Hasil penelitian menemukan bahwa kebijakan publik berpengaruh negatif dan signifikan terhadap kualitas pelayanan dan kinerja organisasi, 
kebijakan publik berpengaruh positif dan signifikan terhadap penguatan kelembagaan dan kinerja organisasi, kualitas pelayanan dan penguatan kelembagaan berpengaruh positif dan signifikan terhadap kinerja organisasi.

Implikasi penelitian ini bahwa kebijakan publik perlu untuk diformulasikan dengan baik sesuai implementasi yang terproses dalam menentukan pencapaian hasil kerja yang dapat dievaluasi dalam mewujudkan kualitas pelayanan, penguatan kelembagaan dan pencapaian kinerja organisasi.

Kata Kuncl: Kebijakan Publik, Kualitas Pelayanan, Penguatan Kelembagaan dan Kinerja Organisasi.

PENDAHULUAN

Birokrasi di Indonesia termasuk

birokrasi pada Pemerintah Provinsi Sulawesi Selatan dalam kenyataannya menunjukkan bahwa birokrasi administrasi yang diterapkan masih perlu dibenahi dan dilakukan transformasi dalam sistem pemerintahan yang mengarah pada tata kelola pemerintahan yang baik. Mewujudkan hal tersebut, maka kebijakan publik, kualitas pelayanan, penguatan kelembagaan dan kinerja organisasi perlu ditingkatkan.

Kebijakan publik menurut Dye (2004) kebijakan sebagai pilihan pemerintah untuk melakukan atau tidak melakukan sesuatu (whatever government chooses to do or not to do). Ini mengandung pengertian bahwa kebijakan pemerintah sebagai kekuasaan mengalokasikan nilai kepentingan untuk masyarakat secara menyeluruh. Termasuk dalam hal ini bagaimana pemerintah memberikan kualitas pelayanan yang terbaik pada publik, selalu meningkatkan penguatan kelembagaan dan pencapaian kinerja organisasi.

Setiap organisasi modern dan maju senantiasa mengedepankan bentuk-bentuk aktualisasi pelayanan publik yang berkualitas. Namun hal tersebut tidak terlepas dari kemampuan pemerintah dalam memberikan pelayanan sesuai kcbutuhan, keinginan dan harapan dari publik. Parasuraman (2001:133) menyatakan wujud pelayanan publik atau pelanggan yang berkualitas ditentukan oleh lima aspek yang biasa dikenal dengan istilah pelayanan yang berkualitas
"RATER" (reliability, assurance, tangible, empathy dan responsivieness). Konsep pelayanan yang berkualitas RATER intinya adalah membentuk sikap dan perilaku dari pengembang pelayanan untuk memberikan bentuk pelayanan yang kuat dan mendasar, agar mendapat penilaian sesuai dengan kualitas pelayanan yang diterima. Ini penting dalam memberikan penguatan terhadap kelembagaan dan pencapaian kinerja organisasi.

Pentingnya penguatan kelembagaan dalam konteks kebijakan administrasi diartikan scbagai sebuah lembaga yang mewadahi kegiatan dan program dari kebijakan yang diterapkan baik bersifat formulasi, implementasi dan evaluasi. Teori kelembagaan menurut Winter (1990) to intoduction of social economy contex in making of policy must have policy formulation, policy implementation process and the result of implementation. Pernyataan Winter tersebut menunjukkan bahwa memperkenalkan konteks sosial ckonomi dalam membuat sebuah input formulasi kebijakan, proses implementasi kebijakan dan hasil evaluasi untuk mencapai tujuan lembaga, schingga lembaga tersebut mampu menjalankan kebijakan dengan baik sesuai kualitas pelayanan untuk mewujudkan pencapaian kinerja organisasi.

Pencapaian kinerja organisasi memungkinkan organisasi tersebut (dalam hal ini organisasi pemerintah) mampu memberikan pelayanan publik yang baik untuk menilai keberhasilan kinerja organisasi. Gap theory yang digunakan untuk membandingkan kesenjangan 
Pleno De Jure, Vol. 4, No. 5, Desember 2015

pengamatan di atas, yaitu mengacu pada teori orientasi hasil (result theory) menurut Fiedler (2008:74) yang mengemukakan bahwa penilaian kinerja organisasi dinilai berdasarkan kuantitas, kualitas, efisiensi, efektivitas dan orientasi tujuan. Penilaian ini harus dinilai secara obyektif berdasarkan hasil kerja organisasi yang memanfaatkan segala sumber daya yang dimilikinya.

\section{TINJAUAN TEORITIS}

Kebijakan Publik

Memahami arti kebijakan publik terlebih dahulu perlu diketahui arti kebijakan. Dye (2004) menyebutkan kebijakan sebagai pilihan pemerintah untuk melakukan atau tidak melakukan sesuatu (whatever government chooses to do or not to do). Pengertian ini mengandung pengertian bahwa kebijakan pemerintah sebagai kekuasaan mengalokasikan nilai kepentingan untuk masyarakat secara menyeluruh.

Aeston (2005) mengartikan kebijakan sebagai sarana untuk menilai pilihan tujuan yang ingin dicapai. Kaplan (2009) kebijakan adalah sarana untuk mencapai tujuan, kebijakan sebagai program yang diproyeksikan berkenaan dengan tujuan, nilai dan praktek (a projected rogram of goals, values and practices). Frederick (2009) menyatakan bahwa yang paling pokok dari suatu kebijakan adalah tujuan (goal), sasaran (objective) dan kehendak (purpose).

Heglond dalam Abidin (2008) menyatakan kebijakan sebagai a course of action intended to accomplish some end", atau suatu tindakan yang bermaksud untuk mencapai tujuan tertentu. Tujuan yang dimaksud yaitu beberapa isu dari suatu kebijakan.

Nugroho (2010) menyatakan bahwa kebijakan lebih dapat dianggap sebagai suatu alat analisis yang menjelaskan berbagai perilaku dalam berbagai hubungan usaha untuk memecahkan permasalahan publik dan memberikan solusi. William (2007) menyatakan kebijakan adalah sisi baru dari perkembangan aktivitas yang mengalami metamorfosis informasi yang relevan untuk memecahkan persoalan publik. Eva (2008) menyatakan kebijakan adalah suatu langkah yang arif dan bijaksana untuk memecahkan persoalan publik dan memberikan solusi yang terbaik.

\section{Kualitas Pelayanan}

Setiap organisasi modem dan maju senantiasa mengedepankan bentuk-bentuk aktualisasi kualitas pelayanan. Kualitas pelayanan yang dimaksud adalah memberikan bentuk pelayanan yang optimal dalam memenuhi kebutuhan, keinginan, harapan dan kepuasan dari masyarakat yang meminta pelayanan dan yang meminta dipenuhi pelayanannya. Parasuraman (2001:26) mengemukakan konsep kualitas pelayanan yang berkaitan dengan kepuasan ditentukan oleh lima unsur yang biasa dikenal dengan istilah kualitas pelayanan "RATER" (responsineness, assurance, tangible, empathy dan reliability). Konsep kualitas pelayanan RATER intinya adalah membentuk sikap dan perilaku dari pengembang pelayanan untuk memberikan bentuk pelayanan yang kuat dan mendasar, agar mendapat penilaian sesuai dengan kualitas layanan yang diterima.

Inti dari konsep kualitas pelayanan adalah menunjukkan segala bentuk aktualisasi kegiatan pelayanan yang memuaskan orang-orang yang menerima pelayanan sesuai dengan daya tanggap (responsiveness), menumbuhkan adanya jaminan (assurance), menunjukkan bukti fisik (tangible) yang dapat dilihatnya, menurut empati (empathy) dari orangorang yang memberikan pelayanan sesuai dengan kehandalannya (reliability) menjalankan tugas pelayanan yang diberikan secara konsekuen untuk memuaskan yang menerima pelayanan.

Inti dari konsep kualitas pelayanan "RATER" kebanyakan organisasi kerja yang menjadikan konsep ini sebagai acuan dalam menerapkan aktualisasi layanan dalam organisasi kerjanya, dalam 
Pleno De Jure, Vol. 4, No. 5, Desember 2015

memecahkan berbagai bentuk kesenjangan (gap) atas berbagai pelayanan yang diberikan oleh pegawai dalam memenuhi tuntutan pelayanan masyarakat. Aktualisasi konsep "RATER" juga diterapkan dalam penerapan kualitas pelayanan pegawai baik pegawai pemerintah maupun non pemerintah dalam meningkatkan prestasi kerjanya.

Dikatakan konsep kualitas pelayanan memenuhi harapan, apabila pelayanan yang diharapkan sama dengan yang dirasakan (memuaskan). Demikian pula dikatakan persepsi tidak memenuhi harapan apabila pelayanan yang diharapkan lebih besar daripada pelayanan yang dirasakan (tidak bermutu) (Parasuraman 2001:165).

Konsep kualitas pelayanan dari harapan yang diharapkan seperti dikemukakan di atas, ditentukan oleh empat faktor, yang saling terkait dalam memberikan suatu persepsi yang jelas dari harapan pelanggan dalam mendapatkan pelayanan. Keempat faktor tersebut adalah pertama, komunikasi dari mulut ke mulut (word of mouth communication), faktor ini sangat menentukan dalam pembentukan harapan pelanggan atas suatu jasa/pelayanan. Pemilihan untuk mengkonsumsi suatu jasa/pelayanan yang bermutu dalam banyak kasus dipengaruhi oleh informasi dari mulut ke mulut yang diperoleh dari pelanggan yang telah mengkonsumsi jasa tersebut sebelumnya.

Kedua, kebutuhan pribadi (personal need), yaitu harapan pelanggan bervariasi tergantung pada karakteristik dan keadaan individu yang mempengaruhi kebutuhan pribadinya. Ketiga, pengalaman masa lalu (past experience), yaitu pengalaman pelanggan merasakan suatu pelayanan jasa tertentu di masa lalu mempengaruhi tingkat harapannya untuk memperoleh pelayanan jasa yang sama di masa kini dan yang akan datang. Dan keempat, komunikasi eksternal (company's external communication) yaitu komunikasi eksternal yang digunakan oleh organisasi jasa jasa sebagai pemberi pelayanan melalui berbagai bentuk upaya promosi juga memegang peranan dalam pembentukan harapan pelanggan.

Berdasarkan pengertian di atas terdapat tiga tingkat konsep kualitas pelayanan yaitu bermutu (quality surprise), bila kenyataan pelayanan yang diterima melebihi pelayanan yang diharapkan pelanggan, memuaskan (satisfactory quality), bila kenyataan pelayanan yang diterima sama dengan pelayanan yang diharapkan pelanggan, dan tidak bermutu (unacceptable quality), bila ternyata kenyataan pelayanan yang diterima lebih rendah dari yang diharapkan pelanggan.

Uraian tersebut di atas, menjadi suatu penilaian di dalam menentukan berbagai macam model pengukuran strategi layanan. Menurut Peter (2003:99) menyatakan bahwa untuk mengukur konsep kualitas pelayanan, maka dilihat dari enam tinjauan yang menjadi suatu penilaian dalam mengetahui konsep kualitas pelayanan yang diadopsi dari temuan-temuan hasil penelitian antara lain scbagai berikut:

Gronroos Perceived Service Quality Model yang dibuat oleh Gronroos. Pendekatan yang dilakukan adalah dengan mengukur harapan akan strategi layanan (expected quality) dengan pengalaman strategi layanan yang diterima (experienced quality) dan antara mutu teknis (technical quality) dengan mutu fungsi (functional quality). Titik fokus dalam perbandingan itu menggunakan citra organisasi jasa (corporate image) pemberi jasa. (Gronroos 1990:55).

Heskett's Service Profit Chain Model. Model ini dikembangkan oleh Heskett's (1990:120) dengan membuat rantai nilai profit. Dalam rantai nilai tersebut dijelaskan bahwa strategi layanan internal (internal quality service) lahir dari karyawan yang puas (employee satisfaction). Karyawan yang puas akan memberi dampak pada ketahanan karyawan (employee retention) dan produktivitas karyawan (employee productivity), yang pada gilirannya akan melahitkan strategi layanan eksternal yang 
Pleno De Jure, Vol. 4, No. 5, Desember 2015

baik. Strategi layanan eksternal yang baik akan melahirkan kepuasan pelanggan (ctustomer satisfaction), kepuasan pelanggan (customer loyalty), dan pada akhirnya meningkatkan penjualan dan profitabilitas.

Normann's Service Management System. Model ini dikembangkan olch Normann's (1992:45) yang menyatakan bahwa sesungguhnya jasa itu ditentukan oleh partisipasi dari pelanggan, dan cvaluasi terhadap strategi layanan tergantung pada interaksi dengan pelanggan. European Foundation for Quality Management Model (EFQM Model). Model ini dikembangkan oleh Yayasan Eropa untuk Management Mutu dan telah diterima secara internasional. Model ini ditemukan setelah lembaga tersebut melakukan survei terhadap organisasi jasa yang sukses di Eropa. Di mana strategi layanan ditentukan oleh faktor kepemimpinan (leadership) dalam mengelola sumberdaya manusia, strategi dan kebijakan, dan sumberdaya lain yang dimiliki organisasi. Proses secara baik terhadap faktor-faktor tersebut akan melahirkan kepuasan kepada karyawan, kepuasan kepada pelanggan dan dampak sosial yang berarti, dan ketiganya merupakan hasil bisnis yang sebenamya.

Service Performance Model (SERPERF Model). Model Taylor yang mengukur tingkat strategi layanan berdasarkan apa yang diharapkan oleh pelanggan (expectation) dibandingkan dengan ukuran kinerja (performance) yang diberikan oleh organisasi jasa dan derajat kepentingan (importance) yang dikehendaki oleh pelanggan (Tjiptono, 2003:99). Service Quality Model (SERVQUAL Model). Model ini dikembangkan oleh Parasuraman, Zeithaml dan Berry. Pengukuran dalam model ini menggunakan skala perbandingan multidimensional antara harapan (expectation) dengan persepsi tentang kinerja (performance). Gaspersz (2003:4) pengertian dasar fari mutu menunjukkan bahwa kata mutu memiliki banyak definisi yang berbeda dan bervariasi dari yang konvensional sampai yang lebih strategik. Definisi konvensional dari mutu biasanya menggambarkan karakteristik langsung dari suatu jasa seperti performansi (performance), keandalan (reliability), mudah dalam penggunaan (ease of use), estetika (esthetics) dan sebagainya, seperti mutu intraksi, mutu lingkungan fisik dan mutu hasil. Dekker (2001:14) pada dasarnya sistem mutu modern itu dibagi menjadi tiga yaitu mutu desain, mutu konfirmasi dan strategi layanan.

\section{Penguatan Kelembagaan}

Pengertian kelembagaan dan organisasi berbeda dalam konteksnya. Kelembagaan menurut James (2008:151) adalah kesatuan (entity) perilaku birokrasi dalam melakukan koordinasi secara sadar melalui berbagai bentuk kerjasima dengan berbagai kepentingan untuk mencapai sebuah tujuan bersama. Robbin (2004:79) menyatakan bahwa organisasi adalah wadah yang melibatkan lebih dari dua orang yang memiliki kompetensi untuk melakukan berbagai kerjasama dalam berbagai kepentingan untuk mencapai tujuan organisasi. Perbedaan yang jelas antara kelembagaan dan organisasi terletak pada pelaku yang menjalankan aktivitas tersebut. Pada kelembagaan dijalankan oleh orang-orang yang memiliki perilaku, sedangkan organisasi dijalankan oleh orang yang memiliki kompetensi Pengertian kelembagaan dalam konteks kebijakan administrasi diartikan sebagai sebuah lembaga yang mewadahi kegiatan dan program dari kebijakan yang diterapkan baik bersifat formulasi, implementasi dan evaluasi. Dasar teori pengertian kelembagaan menurut Winter (1990:207) to intoduction of social econony contex in making of policy must have policy formulation, policy implementation process and the result of implementation. Pernyatan Winter tersebut menunjukkan bahwa memperkenalkan konteks sosial ekonomi dalam membuat sebuah input formulasi 
kebijakan, proses implementasi kebijakan dan hasil evaluasi untuk mencapai tujuan lembaga.

Pengkajian yang akan diangkat dalam kajian ini yaitu memahami pentingnya konteks proses dalam hal ini implcmentasi kelembagaan. Winter (1990:209) menyatakan konteks implementasi kelembagaan ada tiga kajian yang didalami yaitu: 1) perilaku birokrasi antar organisasi (inter organization bureacracy behavior);2) perilaku birokrasi level bawah (street level bureacracy behavior); dan 3) perilaku birokrasi kelompok sasaran (target group bureacracy behavior). Ketiga perilaku birokrasi ini menentukan implementasi kelembagaan dalam mencapai tujuannya. Pentingnya implementasi kelembagaan dalam mencapai tujuan kebijakan, sangat ditentukan oleh adanya serangkaian pelaksanaan perilaku yang menjalankan kelembagaan antar organisasi, level bawa secara hirarki dan kelompok sasaran untuk mewujudkan tujuan (James, 2008:61). Implementasi kelembagaan diperlukan untuk menjelaskan hubungan dan keterkaitan suatu perilaku, tindakan dan hasil yang dicapai dari sebuah implementasi atau pelaksanaan kebijakan (Apter, 2007:76).

\section{Kinerja Organisasi Pemerintahan} Stolovitch and Keeps (2007:92) menyatakan kinerja merupakan seperangkat hasil yang dicapai dan merujuk pada tindakan pencapaian serta pelaksanaan suatu pekerjaan yang diminta. Kinerja merupakan salah satu kumpulan total dari kerja yang ada pada diri pekerja (Griffin, 2008:87). Kinerja dipengaruhi oleh tujuan (Mondy and Premeaux, 2006:3).

Kinerja merupakan suatu
manifestasi hasil yang dicapai. Menyelesaikan tugas atau pekerjaan, seseorang harus memiliki derajat kesediaan mencapai hasil kerja. Seseorang tidaklah memiliki kinerja tanpa pemahaman yang jelas tentang apa yang akan dikerjakan dan bagaimana mengerjakannya untuk menghasilkan sesuatu yang bisa dinilai (Hersey and Blanchard, 2007:93).

Menurut Donnelly, Gibson and Ivancevich (2010:49) kinerja merujuk kepada tingkat keberhasilan dalam melaksanakan tugas serta kemampuan untuk mencapai tujuan yang telah ditetapkan. Kinerja dinyatakan baik dan sukses jika tujuan yang diinginkan dapat tercapai dengan baik sesuai hasil yang dinilai. Pencapaian tujuan yang telah ditetapkan merupakan salah satu tolok ukur kinerja individu.

Ada tiga kriteria dalam melakukan penilaian kinerja individu yakni tugas individu, perilaku individu dan ciri individu (Robbins, 2006:19). Pandangan Furtwengler (2007:36) men' ebutkan ada empat indikator menilai kinerja aktivitas individu dalam organisasi yakni kuantitas, kualitas, efisiensi, efektivitas dan kesetiaan.

Furtwengler (2007:37) menjelaskan bahwa menilai kinerja individu dalam suatu organisasi wujudnya dapat dilihat dari hasil kerja yang dihasilkan secara kuantitas berupa banyaknya pekerjaan yang dihasilkan, secara kualitas mutu kerja yang dihasilkan, selalu mempertimbangkan efisiensi kerja menurut penggunaan waktu kerja dan secara efektif selalu melihat manfaat kerja yang dihasilkan serta patuh pada aturan organisasi.

Kinerja sebagai kualitas dan kuantitas selalu berkaitan dengan efisiensi dan efektivitas sesuai loyalitas dalam bekerja untuk pencapaian tugas-tugas, baik yang dilakukan oleh individu, kelompok maupun organisasi (Schemerhorn, Hunt and Osborn, 2007:91). Kinerja sebagai bagian integral dari hubungan antara organisasi, sumber daya manusia dan hasil kerja. Semakin bagus dukungan organisasi dalam pengembangan sumber daya manusia, semakin menghasilkan kerja yang maksimal sebagai pencerminan kegiatan kinerja. 


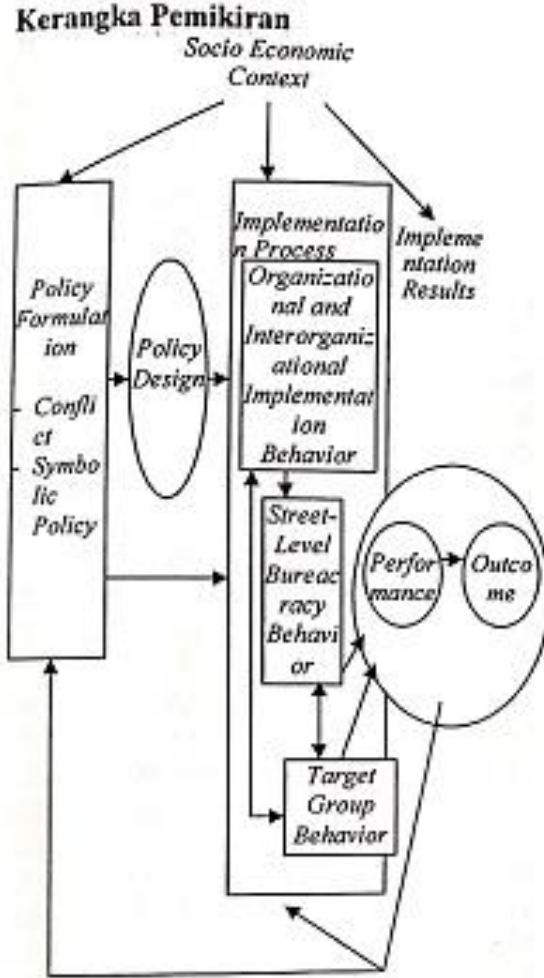

Hipotesis

Pengamatan penelitian ini memberikan tiga hipotesis yang perlu dibuktikan yaitu: $\quad$ 1) kebijakan publik berpengaruh positif dan signifikan terhadap kualitas pelayanan dan kinerja organisasi; 2) kebijakan publik berpengaruh positif dan signifikan terhadap kelembagaan dan kinerja organisasi; dan 3) kualitas pelayanan dan penguatan kelembagaan berpengaruh positif dan signifikan terhadap kinerja organisasi. Hipotesis ini bertujuan untuk membuktikan pengaruh langsung dan tidak langsung terhadap konstruk variabel eksogen terhadap konstruk yariabel endogen di dalam menemukan sebuah hasil penelitian yang dapat direkomendasikan untuk mewujudkan tujuan penclitian.

Metode Penelitian

Bahan yang digunakan dalam penelitian ini yaitu melihat hubungan masing-masing konstruk variabel laten yang diamati, baik berupa variabel laten eksogen sebagai variabel yang mempengaruhi sebagai variabel bebas dan yariabel laten endogen yang dipengaruhi, terdiri dari variabel antara dan variabel terikat. Lebih jelasnya ditunjukkan bahan konstruk dari penelitian ini:

Variabel Laten Eksogen

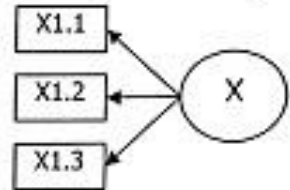

Keterangan:

$\mathrm{X}=$ Kebijakan Publik

$\mathrm{XI} . \mathrm{I}=$ Formulasi

$\mathrm{X} 1.2=$ Implementasi

$\mathrm{X} 1.3=$ Evaluasi

Variabel Laten Endogen (Variabel Antara)

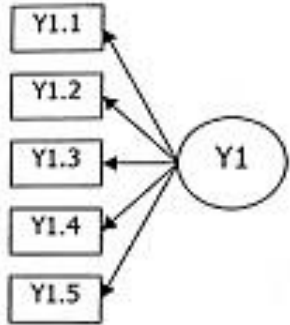

Keterangan:

Y1 = Kualitas Pelayanan

Y1.1 = Daya tanggap

$\mathrm{Y} 1.2=$ Jaminan

$\mathrm{Y} 1.3=$ Bukti Fisik

$\mathrm{Y} 1,4=$ Empati

Y1.S = Kehandalan

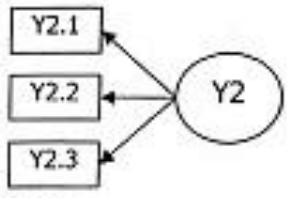

Keterangan:

$\mathrm{Y} 2=$ Penguatan Kelembagaan

Y1.1 = Birokrasi Antar Organisasi 
Pleno De Jure, Vol. 4, No. 5, Desember 2015

Y1.2 = Birokrasi Level Bawah

Y1.3 = Birokrasi Kelompok Sasaran

Variabel Laten Endogen (Variabel Terikat)

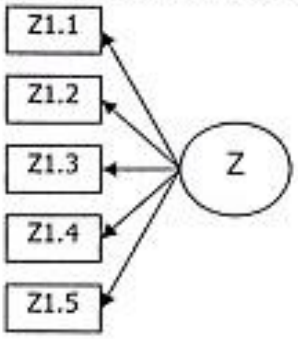

Keterangan:

$\mathrm{Z} \quad=$ Kinerja Organisasi

$\mathrm{Z1.1}=$ Kuantitas

$\mathrm{Z} 1.2=$ Kualitas

$\mathrm{Z1.3}=$ Efisiensi

Z1.4 = Efektivitas

$\mathrm{Z} 1.5=$ Orientasi Tujuan

Teknik analisis data yang digunakan dalam menjelaskan fenomena dalam penelitian ini adalah teknik analisis statistik deskriptif dan analisis Structural Equation Modeling (SEM). Analisis statistik deskriptif yaitu digunakan untuk menganalisis data dengan cara mendeskripsikan atau menggambarkan data yang terkumpul sebagaimana adanya tanpa bermaksud untuk membuat kesimpulan yang berlaku untuk umum (Sugyono, 2009). Analisis statistik deskriptif digunakan untuk menjelaskan karakteristik responden meliputi jenis kelamin, pendidikan terakhir, umur, dan masa kerja. Selain itu, analisis statistik deskriptif juga digunakan untuk menjelaskan tanggapan responden terhadap variabel penelitian. Perhitungan dalam analisis statistik deskriptif dilakukan dengan bantuan komputer menggunakan paket program AMOS 5.0 dan SPSS versi 17.0 .

Structural Equation Model (SEM) adalah teknik analisis statistik inferensial yang mengkombinasikan beberapa aspek yang terdapat pada analisis jalur dan analisis faktor konfirmatori untuk mengestimasi beberapa persamaan secara simultan. Model persamaan struktural
(Structural Equation Modeling) merupakan generasi kedua teknik analisis multivariate yang memungkinkan peneliti untuk menguji hubungan antara variabel yang kompleks baik recursive maupun nonrecursive untuk memperoleh gambaran menyeluruh mengenai keseluruhan model (Ghozali, 2011).

Bollen (dalam Ghozali, 2011) menyatakan bahwa SEM tidak seperti analisis multivariate biasa, hal ini dikarenakan SEM dapat menguji secara bersama-sama. Model struktural (structural model); hubungan antara variabel laten (konstruk) independen dan dependen. Struktural model (model structural) adalah bagian dari SEM yang menggambarkan hubungan an*ar variabel laten. Variabel laten pada model struktural dibedakan menjadi dua macam yakni variabel cksogen dan endogen. Variabel eksogen adalah variabel laten yang tidak dipengaruhi oleh variabel laten yang lainnya dalam model, sedangkan variabel endogen adalah variabel laten yang dipengaruhi oleh variabel laten lainnya dalam suatu model penelitian. Pola hubungan antar variabel laten dalam model struktural ini dianalisis dengan pendekatan path analisis yang identik dengan analisis regresi. Pada model struktural daapt diketahui besar pengaruh variabel eksogen terhadap variabel endogen baik secara langsung maupun tidak langsung.

Model pengukuran (measurement model); hubungan (nilai loading) antara variabel indikator (observasi) dengan variabel konstruk (variabel laten). Measurement model (model pengukuran) adalah bagian dari SEM yang menggambarkan hubungan variabel indikator (observasi) dengan variabel latennya. Hubungan ini dinyatakan dengan faktor loading yang menunjukkan besar korelasi antara indikator dengan variabel latel yang dijelaskannya, dalam melakukan analisa pada model pengukuran ini metode yang digunakan adalah Confirmatory Factor Analysis (CFA). 
Pleno De Jure, Vol. 4, No. 5, Desember 2015

Analisis dan Pembahasan

Analisis hasil penelitian dengan menggunakan model persamaan struktural (Structural Equation Model/SEM) dengan confirmalory factor analysis (CFA) program AMOS 18.0. Kekuatan prediksi variabel observasi baik pada tingkat individual maupun pada tingkat konstruk dilihat melalui critical ratio (CR). Apabila critical ratio tersebut signifikan maka dimensi-dimensi tersebut akan dikatakan bermanfaat untuk memprediksi konstruk atau variabel laten. Variabel laten (construct) penelitian ini terdiri dari kebijakan publik terhadap kualitas pelayanan, penguatan kelembagaan dan kinerja organisasi. Dengan mengeunakan model persamaan struktural dari AMOS akan diperoleh indikator-indikator model yang fit. Tolok ukur yang digunakan dalam menguji masing-masing hipotesis adalah nilai critical ratio (CR) pada regression weight dengan nilai minimum 2,0 secara absolut.

Kriteria yang digunakan adalah untuk menguji apakah model yang diusulkan memiliki kesesuaian dengan data atau tidak. Adapun kriteria model fit terdiri dari: 1) derajat bebas (degree of freedom) harus positif dan 2) non signifikan Chisquare yang disyaratkan $(p \geq 0,05)$ dan di atas konservatif yang diterima $(p=0,10)$ (Hair et al., 2006), 3) incremental fit di atas 0,90 yaitu GFI (goodness of fit index), Adjusted GFI (AGFI), Tucker Lewis Index (TLI), The Minimum Sample Discrepancy Function (CMIN) dibagi dengan degree of freedomnya (DF) dan Comparative Fit Index (CFI), dan 4) RMSEA (Root Mean Square Error of Approximation) yang rendah.

Confirmatory Factor Analysis digunakan untuk meneliti variabel-variabel yang mendefinisikan sebuah konstruk yang tidak dapat diukur secara langsung. Analisis atas indikator-indikator yang digunakan itu memberi makna atas label yang diberikan pada variabel-variabel laten atau konstruk-konstruk lain yang dikonfirmasikan.
Setelah dilakukan uji asumsi dan tindakan seperlunya terhadap pelanggaran yang terjadi berikutnya akan dilakukan analisis model fit dengan kriteria model fit seperti GFI (Goodness of fit index), adjusted GFI (AGFI), Tucker Lewis Index (TLI), CFI (Comparative of fit index), dan RMSEA (Root Mean Square Error of Approxination) baik untuk model individual maupun model lengkap. Hasil pengukuran terhadap dimensi-dimensi atau indikator variabel yang dapat membentuk suatu konstruk atau variabel laten (latent variable) dengan confirmatory factor analysis secara berturut-turut dijelaskan sebagai berikut:

Hasil uji konstruk variabel eksogen kebijakan publik dievaluasi berdasarkan goodness of fit indices pada Tabel 1 be:ikut dengan disajikan kriteria model serta nilai kritisnya. Dari evaluasi model yang diajukan menunjukkan bahwa evaluasi terhadap konstruk secara keseluruhan menghasilkan nilai kritis yang menunjukkan bahwa model telah sesuai dengan data, sehingga dapat dilakukan uji kesesuaian model selanjutnya.

Tabel 1

Evaluasi kriteria Goodness of Fit Indices Variabel Eksogen

\begin{tabular}{|c|c|c|c|}
\hline $\begin{array}{l}\text { Goodncess } \\
\text { of nit indes }\end{array}$ & $\begin{array}{l}\text { Cut-of } \\
\text { Value }\end{array}$ & $\begin{array}{l}\text { Fasil: } \\
\text { Modele }\end{array}$ & Ket. \\
\hline Chi_Square & $\begin{array}{c}\text { Dihara } \\
\text { pknn } \\
\text { kecil }\end{array}$ & 111,577 & Mtarginal \\
\hline Probability & $\geq 0.05$ & 0,000 & Marginal \\
\hline CMIN/DF & $\leq 2.00$ & 7,970 & Marginal \\
\hline RMSEA & $\leq 0.08$ & 0,138 & Marginal \\
\hline GFI & $\geq 0.90$ & 0,912 & Baik \\
\hline AGFI & $\geq 0.90$ & 0,824 & Marginal \\
\hline TLI & $\geq 0.94$ & 0,678 & Marginal \\
\hline $\mathrm{CFI}$ & $\geq 0.94$ & 0,824 & Marginal \\
\hline
\end{tabular}

Sumber: Hasil Olah Data

Tabel I menunjukkan bahwa model pengukuran variabel eksogen menunjukkan model fit kurang fit antara data dengan model. Hal ini dibuktikan dari delapan criteria yang tidak terpenuhi. Dengan 
Pleno De Jure, Vol. 4, No. 5, Desember 2015

demikian model di atas menunjukkan tingkat penerimaan yang kurang baik oleh karena itu dapat disimpulkan bahwa model perlu dianalisis lebih lanjut.

Selanjutnya untuk mengetahui variabel yang dapat digunakan diamati dari nilai regresi dan tingkat signifikansinya ( $p$ ${ }^{* * *}$ ) artinya nilai probabilitas $<0.05$ atau 0.000 , yang mencerminkan masing-masing variabel sebagai indikator variabel eksogen tampak pada tabel 2 .

Tabel 2

Nilai Regresi untuk Pengukuran Indikator Variabel Eksogen

\begin{tabular}{|c|c|c|c|c|}
\hline $\begin{array}{l}\text { Variabel } \\
\text { Indilikator. }\end{array}$ & $\begin{array}{l}\text { Loading } \\
\text { Faktor } \\
(2)^{2}\end{array}$ & $\begin{array}{l}\text { Critica } \\
\text { IRatio: }\end{array}$ & $\begin{array}{l}\text { Prob: } \\
\text { abilin } \\
\text { bys }\end{array}$ & Ket \\
\hline$\overline{X 1}$ & 0,229 & 3,839 & 0,000 & $\begin{array}{l}\text { Signif } \\
\text { ikan }\end{array}$ \\
\hline $\mathrm{X} 2$ & 0,587 & 9,817 & 0,000 & $\begin{array}{l}\text { Signif } \\
\text { ikan }\end{array}$ \\
\hline $\mathrm{X3}$ & 0,280 & 4,659 & 0,000 & $\begin{array}{l}\text { Signif } \\
\text { ikan }\end{array}$ \\
\hline
\end{tabular}

Sumber: Hasil Olah Data

Loading faktor $(\lambda)$ pengukuran variabel eksogen pada Tabel 13 menunjukkan hasil uji terhadap model pengukuran variabel dari setiap indikator yang menjelaskan konstruk, sehingga seluruh indikator diikutkan dalam pengujian berikutnya.

Hasil uji $C F A$ variabel endogen yaitu kualitas pelayanan $\left(\mathrm{Y}_{1}\right)$, penguatan kelembagaan $\left(Y_{2}\right)$ dan kinerja organisasi (Z) terhadap model. Hasil uji konstruk variabel endogen dievaluasi berdasarkan goodness of fit indices pada Tabel 3 berikut dengan disajikan kriteria model serta nilai kritisnya. Dari evaluasi model yang diajukan menunjukkan bahwa evaluasi terhadap konstruk secara keseluruhan menghasilkan nilai kritis yang menunjukkan bahwa model telah sesuai dengan data, sehingga dapat dilakukan uji kesesuaian model selanjutnya.
Tabel 3

Evaluasi kriteria Goodness of Fit Indices Variabel Endogen

\begin{tabular}{|cccc|}
\hline Goodness & Cut-off & Hasil & Ket \\
of fit & Value & Model & \\
\hline $\begin{array}{c}\text { index } \\
\text { Chi_squar } \\
e\end{array}$ & $\begin{array}{c}\text { Diharap } \\
\text { kan kecil }\end{array}$ & $\begin{array}{c}199,94 \\
2\end{array}$ & Marginal \\
\hline $\begin{array}{c}\text { Probabilit } \\
y\end{array}$ & $\geq 0,05$ & 0,000 & Marginal \\
\hline CMIN/DF & $\leq 2,00$ & 3,920 & Marginal \\
\hline RMSEA & $\leq 0,08$ & 0,090 & Marginal \\
\hline GFI & $\geq 0,90$ & 0,905 & Baik \\
\hline AGFI & $\geq 0,90$ & 0,855 & Marginal \\
\hline TLI & $\geq 0,94$ & 0,791 & Marginal \\
\hline CFI & $\geq 0,94$ & 0,838 & Marginal \\
\hline
\end{tabular}

Sumber: Hasil Olah Data

Tabel 3 menunjukkan bahwa model pengukuran variabel endogen menunjukkan model fit atau kesesuaian antara data dengan model. Hal ini dibuktikan dari delapan criteria yang sudah terpenuhi. Dengan demikian model di atas menunjukkan tingkat penerimaan yang baik oleh karena itu dapat disimpulkan bahwa model dapat diterima.

Selanjutnya untuk mengetahui variabel yang dapat digunakan sebagai indikator dari variabel endogen dapat diamati dari nilai regresi dan tingkat signifikansinya $\left(\mathrm{p}^{* * *}\right)$ artinya nilai probabilitas $<0.05$ atau 0.000 , yang mencerminkan masing-masing variabel sebagai indikator kinerja tampak pada tabel 4.

Tabel 4

Nilai Regresi untuk Pengukuran Indikator Variabel Endogen

\begin{tabular}{|c|c|c|c|c|}
\hline $\begin{array}{l}\text { Kunalitas } \\
\text { Pclayana } \\
\text { n(Y1) }\end{array}$ & $\begin{array}{l}\text { Loagdi } \\
\text { ng: } \\
\text { Fakito } \\
\mathrm{r}(\lambda)\end{array}$ & $\begin{array}{c}\text { Criti } \\
\text { cal } \\
\text { Ratio }\end{array}$ & $\begin{array}{l}\text { Probnai } \\
\text { lity }\end{array}$ & $\begin{array}{c}\text { Keteran } \\
\text { gan }\end{array}$ \\
\hline Y1.1 & 0,408 & 6,719 & 0,000 & $\begin{array}{c}\text { Signifika } \\
\mathrm{n}\end{array}$ \\
\hline $\mathrm{Y} 1.2$ & 0,414 & 7,227 & 0,000 & $\begin{array}{c}\text { Signifika } \\
\mathbf{n}\end{array}$ \\
\hline Y1.3 & 0,808 & FIX & 0,000 & $\begin{array}{c}\text { Signifika } \\
n\end{array}$ \\
\hline Y1.4 & 0,606 & $\begin{array}{c}10,38 \\
7 \\
\end{array}$ & 0,000 & $\begin{array}{c}\text { Signifika } \\
\mathrm{n}\end{array}$ \\
\hline
\end{tabular}


Pleno De Jure, Vol. 4, No. 5, Desember 2015

\begin{tabular}{|c|c|c|c|c|}
\hline Yt.5 & 0,566 & 9,705 & 0,000 & $\begin{array}{c}\text { Signifika } \\
n\end{array}$ \\
\hline \multicolumn{5}{|c|}{$\begin{array}{l}\text { Penguata } \\
\text { n } \\
\text { Kelemba } \\
\text { gaan }\left(Y^{2}\right) \\
\end{array}$} \\
\hline YZ.1. & 0,470 & 7,946 & 0,000 & $\begin{array}{c}\text { Signifika } \\
n\end{array}$ \\
\hline$Y 2.2$ & 0,716 & FIX & 0,000 & $\begin{array}{c}\text { Signifika } \\
\mathrm{n}\end{array}$ \\
\hline $\bar{\gamma} 2.3$ & 0,516 & 8,488 & 0,000 & $\begin{array}{c}\text { Signifiks } \\
n\end{array}$ \\
\hline \multicolumn{5}{|c|}{$\begin{array}{l}\text { Loyalitas } \\
\text { (Z) }\end{array}$} \\
\hline Z1.I & 0,235 & 4,439 & 0,000 & $\begin{array}{c}\text { Signifika } \\
n\end{array}$ \\
\hline $\mathrm{Z1.2}$ & 0,617 & FIX & 0,000 & $\begin{array}{c}\text { Signifika } \\
n\end{array}$ \\
\hline 21.3 & 0,215 & 4,041 & 0,000 & $\begin{array}{c}\text { Signifika } \\
n\end{array}$ \\
\hline 21.4 & 0,527 & FIX & 0,000 & $\begin{array}{c}\text { Signifika } \\
\mathrm{n}\end{array}$ \\
\hline 21.5 & 0,315 & 5,114 & 0,000 & $\begin{array}{c}\text { Signiffka } \\
\mathrm{n}\end{array}$ \\
\hline
\end{tabular}

Loading faktor ( $\lambda$ ) pengukuran variabel endogen pada Tabel 4 menunjukkan hasil uji terhadap mode] pengukuran variabel endogen dari sctiap indikator yang menjelaskan konstruk, sehingga seluruh indikator diikutkan dalam pengujian berikutnya.

Berdasarkan cara penentuan nilai dalam model, maka variabel pengujian model pertama ini dikclompokkan menjadi variabel eksogen (exogenous variabel) dan variabel endogen (endogenotis variable). Variabel eksogen adalah variabel yang nilainya ditentukan di luar model. Sedangkan variabel endogen adalah variabel yang nilainya ditentukan melalui persamaan atau dari model hubungan yang dibentuk. Termasuk dalam kelompok variabel eksogen adalah kebijakan publik, sedangkan yang tergolong variabel endogen adalah kualitas pelayanan, penguatan kelembagaan dan kinerja organisasi.

Model dikatakan baik bilamana pengembangan model hipotetik secara leoritis didukung oleh data empirik. Dari evaluasi model menunjukkan dfri dclapan kriteria goodhess of fit indices terlihat nilai ehi-squarenya masih besar dau masih terdapat kriteria yang tidak sesuai dengan nilai cut off young ditentukan, sehingga dilakukan modifikasi model dengan melakukan korelasi antar error indikator scsuai dengan petunjuk dari modification indices. Hasil uji model dievaluasi berdasarkan goodness of fit indices pada tabel 5 berikut dengan disajikan kriteria model serta nilai kritisnya yang memiliki kescsuaian data.

Tnbel 5

Evaluasi kriteria Goadness of Fit Indices Overall Mousel

\begin{tabular}{|c|c|c|c|}
\hline $\begin{array}{l}\text { Gooninets } \\
\text { of it index }\end{array}$ & Gut-ofi & $\begin{array}{l}\text { Insis } \\
\text { Mrodel }\end{array}$ & Keterangan \\
\hline Chi_Square & $\begin{array}{c}\text { Diharapkan } \\
\text { kecil }\end{array}$ & 137,202 & Baik \\
\hline Probsbility & $\geq 0.05$ & 0,053 & Baik \\
\hline CMINIDF & $\leq 2.00$ & 1,225 & Baik \\
\hline RMSEA & $\leq 0.08$ & 0,025 & Baik \\
\hline GFI & $\geq 0.90$ & 0,964 & Baik \\
\hline AGFI & $\geq 0.90$ & 0,938 & Baik \\
\hline TLI! & $\geq 0.94$ & 0,979 & Baik \\
\hline $\mathrm{CFI}$ & $\geq 0.94$ & 0,986 & Baik \\
\hline
\end{tabular}

Sumber ; Hair (2006), Arbuckle (1997)

Dari evaluasi model menunjukkan delapan kriteria goodness of fit indices telah memenuhi kriteria cut off value, sehingga model dapat dikatakan telah sesuai dengan kriteria goodness of fit indices untuk di analisis.

Berdasarkan model empirik yang diajukan dalam penelitian ini dapat dilakukan pengujian terhadap hipotesis yang diajukan melalui pengujian koefisien jalur pada model persamaan struktural. Tabel 6 merupakan pengujian hipotesis dengan melihat nilai $p$ value, jika nilai $p$ value lebih kecil dari 0.05 maka hubungan antira variabel signifikan. Selain itu juga menjelaskan pengaruh langsung (direct effect) artinya terdapat pengaruh yang positif secara langsung antara variabel, pengaruh tidak langsung (indirect effect) artinya terdapat pengaruh yang positif secara tidak langsung antara variabel, dan pengaruh total (total effect) yaitu 
akumulasi dari pengaruh langsung dan tidak langsung. Hasil pengujian disajikan pada tabel berikut:

Tabel 6

Pengujian Hipotesis

\begin{tabular}{|c|c|c|c|c|c|c|c|c|}
\hline \multirow{3}{*}{$\begin{array}{l}\text { HIP } \\
\qquad 1\end{array}$} & \multicolumn{3}{|c|}{ Vanisbel } & \multicolumn{3}{|c|}{ Standardize } & \multirow[b]{2}{*}{$\begin{array}{l}\text { P.Va } \\
\text { lue }\end{array}$} & \multirow[b]{2}{*}{ Ket } \\
\hline & $\begin{array}{c}\text { Exsog } \\
\text { en }\end{array}$ & \multicolumn{2}{|c|}{ Endozen } & Direct & $\begin{array}{c}\text { Ind } \\
\text { istec } \\
1 \\
\end{array}$ & Toal & & \\
\hline & $\begin{array}{l}\text { Kebiy } \\
\text { akan } \\
\text { Publik } \\
\text { (X) }\end{array}$ & $\begin{array}{c}\text { Kualitas } \\
\text { Pelayanan } \\
\text { (YI) }\end{array}$ & $\begin{array}{c}\text { Kincetja } \\
\text { Organisa } \\
\text { si (Z) }\end{array}$ & $-0,633$ & $\begin{array}{l}0.3 \\
34\end{array}$ & -0.299 & $\frac{0.02}{8}$ & $\begin{array}{c}\text { Sigh } \\
\text { ifika } \\
n\end{array}$ \\
\hline 2 & $\begin{array}{c}\text { Kety } \\
\text { akan } \\
\text { Publik } \\
{[\mathrm{X}]} \\
\end{array}$ & $\begin{array}{l}\text { Pengusath } \\
\text { Keiembajpa } \\
\text { an (Y2) }\end{array}$ & $\begin{array}{c}\text { Kinerja } \\
\text { Onganisa } \\
\text { sa } \\
(Z) \\
\end{array}$ & 0.588 & $\begin{array}{l}0.2 \\
73\end{array}$ & 0.861 & $\begin{array}{c}0,00 \\
0\end{array}$ & $\begin{array}{l}\text { Sipn } \\
\text { ifika } \\
=\end{array}$ \\
\hline \multirow[b]{2}{*}{3} & - & $\begin{array}{c}\text { Citn } \\
\text { Perusilatan } \\
\text { (YI) }\end{array}$ & \multirow{2}{*}{$\begin{array}{c}\text { Kinerias } \\
\text { Oreanisa } \\
\text { si } \\
\text { (z) }\end{array}$} & 0.353 & $\begin{array}{l}0.0 \\
00\end{array}$ & 0.353 & $\begin{array}{c}0,00 \\
8\end{array}$ & \begin{tabular}{|c|} 
Sipr \\
ifika \\
n \\
\end{tabular} \\
\hline & " & $\begin{array}{c}\text { Kepuasan } \\
\text { Pelangzan } \\
\text { (Y2) }\end{array}$ & & 0.774 & $\begin{array}{l}0,0 \\
00\end{array}$ & 0.774 & $\underset{0}{0.00}$ & \begin{tabular}{|c} 
Sien \\
ifika \\
n
\end{tabular} \\
\hline
\end{tabular}

Sumber: Hasil Olah Data

Interpretasi dari Tabel 6 dapat dijelaskan bahwa kebijakan publik berpengaruh negatif dan signifikan terhadap kualitas pelayanan dan kinerja organisasi dengan $p=0.028<0.05$, dengan nilai pengaruh langsung -0.633 dan pengaruh tidak langsung 0.334 . Kebijakan publik berpengaruh positif dan signifikan terhadap penguatan kelembagaan dan kinerja organisasi dengan $p=0.000<0.05$, dengan nilai pengaruh langsung 0.588 dan pengaruh tidak langsung 0.273 . Kualitas pelayanan dan penguatan kelembagaan berpengaruh positif dan signifikan terhadap kinerja organisasi. Untuk kualitas pelayanan terhadap kinerja organisasi dengan $p=0.008<0.05$ dan nilai pengaruh langsung 0.353 , dan untuk penguatan kelembagaan terhadap kinerja organisasi dengan $p=0.000<0.05$ dan nilai pengaruh langsung 0.774 .

\section{SIMPULAN DAN SARAN Simpulan}

Hasil penelitian menyimpulkan dengan implikasi bahwa kebijakan publik berpengaruh negatif dan signifikan terhadap kualitas pelayanan dan kinerja organisasi. Implikasi kualitas pelayanan tidak ditcrapkan dengan baik, sehingga aparatur pemerintah menurun. Direkomendasikan tuntuk terus mengambil keputusan kebjjakan publik yang strategis yang berbasis kualtias pelayanan dan kinerja.

Kebijakan publik berpengaruh positif dan signifikan terhadap penguatan kelembagaan dan kinerja organisasi. Implikasinya, kelembagaan organisasi semakin solid dalam pencapaian kinerja. Direkomendasikan untuk mempertahankan kebijakan berorientasi kelembagaan dan kinerja.

Kualitas pelayanan dan penguatan kelembagaan berpengaruh positif dan signifikan terhadap kinerja organisasi. Implikasinya, kinerja organisasi semakin berkualitas dan terlembagakan. Dirckomendasikan untuk mengembangkan kualitas layanan yang terlembaga.

\section{Saran}

Berdasarkan simpulan di atas, disarankan untuk terus mengambil keputusan kebijakan publik yang strategis yang berbasis kualtias pelayanan dan kinerja, mempertahankan kebijakan berorientasi kelembagaan dan kinerja, serta mengembangkan kualitas layanan yang terlembaga.

\section{DAFTAR PUSTAKA}

Aaeston, Henry, 2005. Values and Public Policy. Journal of Public Research 38 February 2000 . 131-142..

Apler, Charles, 2007. An Introduction to the Study of Public Policy. $2^{\text {th }}$, Journal of public intelligence \& planning 16/1:47-55..

Dekker, Mascule, 2001. Application Organiztion Service in Globalization Era. http://www, journaloforganization,c om.id.

Dye, Thomas R, 2004. Understanding Public Policy. Joumal of Planning Public Administration, 12/1:36.90. 
Pleno De Jure, Vol. 4, No. 5, Desember 2015

Phenomenon. Public Policy as Public Admon, Journal of Planning Public Administration, 13/4:22.25.

Eva, Deirmand, Y, 2008. Public Policy Making Reexamined. Journal of Performance 18(9): 175-183.

Fiedler, George, 2008. Performance and Management. Published by Harper T \& Row, New York.

Frederick, Ackooff, 2009. A Systems Approach of Public Policy. Joumal of Research Administration 7(12): 210-215.

Furtwengler, Dale, 2007. Performance. Published by Harper T \& Rows, New York.

Gibson, James L, Ivancevich, John M and Donnely, James, 2004 Organizational Behavior, Siructure, Process. Journal of Business Systems, Governance and Ethics Vol. 5 No. 2.

Groonross, A. Steven, 1990, Measure Service Quality: Reexamination and Extension. Journal of Marketing. Vol. 56. July, 55-68.

Heskett, Briyan, 1990. Autonomy in Concept and Theory of Public Policy. Leadership \& Organization Development Journal Vol. 25 Number 2, 2004, pp: 161-179. Emerald Group Publishing Limited 0143-7739.

James R. Lindner, 2008. Competency Assessment and Human Resource Management Performance of County Extension Chairs. Journal of Research Management 15(8): 182-190.

Kaplan. Marshall, 2009, Performance by Human Resotrice Management
Handbook. Organization Science Vol. 6 No, 2 March - April.

Mondy, Marvel and Premeaux, Walton, 2006. The Flexible Firm of Performance by Human Resource Development. Joumal Of Administration Vol. 36 No $7 / 8$ pp. $811-828$.

Norman, Katz, 1992. Foundalion of Behavioral Public Policy. Joumal of Public Administration. Vol. 65,34-49.

Parasuraman, A., Valarie, 2003. SERVQUAL: A multi-ilem scale for measuring Consumer Perceptions Of Service Quality. Journal Of Retailing Vol. 65(1): 12-36.

Peter, Anderson, 2003. Reimventing Public Policy. London: Butterworth \& Heinemman.

Robbins, Stephen, P., 2004. Organizational Behavior. ISSN 2224-6096 (print) ISSN 2225-0581 (online) Vol. 1,2011.

Schemerhorn, French, Hunt, Briant, and Osborn, 2007. Human Resource in Performance Management. International Journal of Academic Research in Business and Social Sciences, August, 2013 Vol. 3 No. 8.

Stolovitch, Storryl, and Keeps, Storey, 2007. Managing Resource and Performance. Joumal of Management and Performance, 36(5): 136-149..

Sugiyono, 2009. Melodologi Penelitian. Penerbit Gunung Agung, Jakarta.

Stolovitch, Storryl, and Keeps, Storey, 2007. Managing Resonrce and Perfonnance. Academy of 
Management Journal Vol. 34 No. $34,827-847$.

Tjiptono, Fhandy, 2007. Strategi Pemasaran. Penerbit PT. Gramedia Pustaka, Jakarta.

William, Wayne, 2007. A Introduction of Theory and Practice of Public Analysis. Journal of Research Management S(8): 122-125.

Winter, Soren C, 1990. Implementation Perspectives: Statue and Reconsideration. Dalam Peters, B Guy and Pierre, Jon, 2003. Handbook of Public Administration. London: Sage Publici.sions Ltd. 